\title{
Amputating the State: Autonomy and La Universidad de la Tierra
}

\author{
Matthew Carlin
}

The problem of education is not an ideological problem but the problem of the organization of power: it is the specificity of educational power that makes it appear to be an ideology, but its pure illusion.

Gilles Deleuze, 2009, p. 36

The State is desire that passes from the head of the despot to the hearts of his subjects, and from the intellectual law to the entire physical system that disengages or liberates itself from the law.

Gilles Deleuze and Félix Guattari, 1983, p. 221

\section{Unitierra: Not a school}

A dusty road leads up to La Universidad de la Tierra (the University of the Land, also known as 'Unitierra') on the outskirts of La Colonia Ampliación Maravilla en San Cristóbal de Las Casas, Chiapas Mexico. San Cristóbal is the main colonial town in the state of Chiapas, the southernmost state in Mexico as well as home to the largest percentage of indigenous people in all of Mexico. It was also, famously, one of the primary sites for the 1994 neo-Zapatista uprising where indigenous people from all over Chiapas took over the seven major towns of Chiapas and began their long journey toward the creation of what they call an autonomous life.

San Cristóbal lies high in the mountains, almost 7,000 feet up and is populated by a mixture of coletos- typically light skinned, wealthy economic and political elites who still claim some affinity and connection to the original Spanish colonizers in the region, and the indigenous Mayan peoples (the 
Tzotziles, Tzeltales, Choles, Tojolobales, Mames, etc.) who are poor, largely uneducated, and live on the margins of the town. The town is named after one of the first bishops of Chiapas, Bartolomé de las Casas who was known as that 'protector of Indians' - a benefactor of 'Indians' for the simple fact that he advocated using Africans instead of 'Indians' as slaves. The city was founded in 1528 and served as the capital of Chiapas until 1892 when Tuxtla Gutiérrez took over as the primary urban and political centre of the State - about the same time that Mexico annexed the state of Chiapas from Guatemala. The combination of being the last state to be formally annexed to Mexico and, at the same time, being a state full of 'Indians', speaks to the way that Chiapas has always seemed to have one foot in and one foot out of the nation.

The city's link to the old colonial days are as evident in starkly defined lines between the rich and poor as they are in the actual homes one comes across while walking around - run-down shanty towns that exist on the surrounding hills on the outskirts stand in contrast to the adobe, red roofed buildings in the centre of town rumoured to be some of the oldest original colonial structures in the whole of Latin America - with the oldest of these (reportedly the oldest in all of Latin America) now serving as a trendy restaurant and night spot for tourists called La Paloma. Sitting almost 7,000 feet above sea level the days are filled with intense sun while the nights are almost always cool - a contrast that seems to do nothing but reinforce the social and cultural forms of stratification that exist between the people who inhabit this place.

In spite of its size - less than 100,000 people - it is still an urban area and as such it is (unlike much of rural Chiapas where formal education is either non-existent or terribly insufficient) the home to many elementary, middle, and prep schools. There are also a number of universities in San Cristóbal: the Autonomous University of Chiapas (UNACH); the Center of Superior Anthropological Research (CIESAS); and the Chiapas Highland University $(\mathrm{UACH})$, among others. There is one university, however, that is not part of the national system of schools and universities and that is La Universidad de La Tierra - the University of the Land or Unitierra as it is often called by locals. In fact, in spite of the use of 'university' in the title, La Universidad de La Tierra is, from the perspective of those who work there, not a school at all. It is however, part of a larger education project called The Indigenous Intercultural System of Informal Education that, along with Unitierra, includes the Indigenous Center for Integral Work; the Center for Intercultural Studies; the Center of Immanuel Wallerstein Studies; and the University Center of Open and Distance Education, all of which are all located on the same 20 -acre parcel of land. 
To get to Unitierra from town is not difficult, but it is located on the periphery of San Cristóbal on a stretch of hills that surround the city. The hills are forested - covered in young pine trees and rocks that sporadically appear amidst eroded top soil. The hills are not that high. However, at the top, one can see the whole of San Cristóbal and way that the four principal churches are aligned on the edges of town in the shape of a cross.

The university was not always located in the place where it currently stands. Unitierra started as a school on the opposite end of town as a project of the Catholic Church and Bishop Samuel Ruiz - the famous liberation theologian who died in 2011 and drove the local coletos crazy with his constant talk of working for a better life for the poor and indigenous. Tatik, the Mayan word for father, is what his congregation called him out of reverence.

In its original spot in 1983, the project began as a vocational school for indigenous students. It was a way for youth from surrounding rural communities to train for a trade that might allow them to someday find a job as a mechanic, carpenter, hairdresser, shoemaker, electrician, etc., while helping to provide monetary relief to their own farming communities that typically have only sporadic or seasonal access to actual money.

Six years later, in 1989, the school moved from one end of San Cristóbal to its current location in the northern part of the town and in the process cut all previously-established connections it had to civic life, including the use of any resources traditionally supplied by the government including electricity, land, and water. Although in 1989 the full force of the political upheaval that would accompany the enactment of NAFTA (the North American Free Trade Agreement) and the rise of the neo-Zapatistas in 1994 were still to come, the decoupling of Unitierra from any and all government support or sponsorship is an indication that the dreams of neo-Zapatista autonomy were already well on their way to coming to fruition in the late 1980s.

Unitierra is easy enough to visit provided that one has a specific intention. For example, if you know someone who works there; that would like to learn more about Unitierra; or attending one of various academic events that occur throughout the year and are open to the public. Unitierra students sometimes attend the academic events, but the majority of the attendees come from the surrounding community and universities.

As one gets closer to the entrance, the beautifully designed and brightly coloured buildings become more visible. The buildings are made of brick and wood, brightly coloured and painted cement, wooden frames, and orange tiled or red aluminum-roofs. An open garage that serves as a training centre for 
mechanics sits about 50 metres in front of the entrance where cars and trucks of various sizes stand out front. Other buildings are situated to the left and right with each one serving as a site for a specific kind of training, study, and learning. The majority of one- and two-storey buildings (and there are eight in total) are circular, and all of them are painted with a specific colour that indicates its function. These buildings are often two-floor structures, that have multiple open rooms and levels. The spatial organization within the structures allows for different tasks and kinds of work/training to be going on simultaneously.

Gravel and dirt paths weave between all of the different structures in the area. The building with the orange trim is the site where students learn to be electricians, learn to do metalwork and soldering, and repair electronic equipment. The yellow building is the art building where students can learn to draw, paint, and sculpt. The pink building is the university health centre where students work and train as nurses while learning about basic nutrition and forms of healthcare. The green buildings mark the site of the university farm where rabbits, pigs, chickens, sheep, and ducks are bred, and a variety of vegetables are grown. There are also buildings where students can learn to weave, train in computer science and computer repairs, learn architecture and design, study music and learn to play marimba, piano, guitar, harp, accordion, violin, trumpet, saxophone, and sing. In each site, the students not only learn a particular skill, but also learn how to take care of and repair the equipment they use.

There is also a tortillería on campus, a communal kitchen and dining area where all of the students come together, taking turns to serve, cook, and clean. There is also a chapel where the entire community comes together for services and other gatherings, separate sleeping quarters for men and women, and a building that serves as a centre for academic seminars, classes, and conferences that are attended by both students and faculty from different parts of Chiapas. For director Raymundo Sánchez, Unitierra was created in response to the growing need to provide indigenous youth, who are for one reason or another, unable to attend a local school, the possibility to develop a skill or train for a profession regardless of their level of official, State- sponsored schooling. According to Sánchez, the three primary pedagogical goals are: (1) to learn by doing; (2) to learn to learn; and 3) to learn to be more, in terms of developing an autonomous existence as a 'countertendency' to the modern world. As Sánchez (2005), points out, this 'countertendency' might only have 'the power of an ant', but it is something they are completely committed to.

The first principle, 'to learn by doing', is a product of the fact that students can come and be part of Unitierra for a few weeks, one month, nine months, 
or longer. Regardless of the amount of time that students are away from or able to leave their communities, Unitierra is organized and facilitated in a way that allows students to immediately benefit from their time there by immediately being engaged in specific kinds of vocational activities and collective, autonomous life. As soon as they arrive, they begin to study and work.

The second principle, 'learning to learn', is oriented toward helping students become better self-learners. This self-learning coincides with the autonomous, collective life that exists at Unitierra and in dispersed autonomous Zapatista municipalities, that refuse to rely on government institutions as the source of their education.

The third principle is what Sánchez claims is the most important, namely that the collective life of the school and the kinds of activities and education taking place at Unitierra work to maintain the kind of life that exists in indigenous communities where greed, although present, does not dominate everyday life. As a deterrent to the mathematicization of the social body and concomitant privatization of social needs inherent to neo-liberal global capitalist culture, ${ }^{1}$ the kinds of pre-colonial forms of collective and collaborative relationships to each other and the land, typical of many rural indigenous communities today, are maintained and defended as an integral part of the everyday lives of the students who live and work there.

The specific activities and workshops in which these students are trained are organic agriculture and technology that is organized around the spheres of domestic, artisanal, and technical kinds of work and training. All of the students that participate in these activities, regardless of their specific sphere of training, also participate in workshops focused on community nutrition and health issues.

The recognition for this education project is sought in the indigenous communities it serves in Chiapas; avoiding at all costs, its legitimation and capture by the State. In other words, the State does not recognize the kinds of education taking place at Unitierra, and the students and facilitators who live and work at Unitierra prefer it that way.

In total about 400 or so students live, study and work at Unitierra. Any and all of these students are allowed to participate in as many of the organized workshops and training sites as they want and which their schedule allows. The students come from all around the state and speak a variety of languages including Tzeltal, Tzotzil, Tojolobal, Chol, and Mam. In spite of the language

1 See Berardi (2012) for more on this link between mathematics and global finance. 
differences that are more pronounced among the young women who enter the university and often do not speak Spanish, all of the students work, sleep, and study together. These students also take an active role in the functioning of the school including both making and serving breakfast, lunch, and dinner to all the people that work and reside there. A rotating schedule ensures that everybody participates, at one time or another, in all of the work necessary to keep the school functioning. Students who have been engaged in their chosen field of work/study also participate in facilitating and helping new students in their work.

There are no prerequisite requirements for entrance, and tuition and living on site is free. With food (including the corn and masa (dough made from corn)), water, and energy provided in the grounds, and furniture, and clothing made there, Unitierra is almost completely self-sufficient. However, students, along with their parents and parish representatives must have a meeting the director before being admitted. Students arrive from the surrounding mountains and jungle with the simple desire to learn a trade that will allow them to make a small amount of money for themselves and their families, and also to actively explore and participate in the expansion of the plan for indigenous autonomy in Chiapas.

\section{Autonomy and el Estado}

The Zapatistas - the indigenous-led Anarcho-Marxist social movement that took the world by storm in 1994 and has since almost completely disappeared from the public eye, continue their attempt to create an autonomous life more than nineteen years after their initial uprising. Although there is no official or formal acknowledgement of Unitierra's connection to the Zapatistas, there are political murals of EZLN (Zapatista Army of National Liberation) commanders that adorn buildings that are named after such figures as Immanuel Wallerstein and Ivan Illich. There are also whispers that Raymundo Sánchez was one of the original commanders of the EZLN during the 1994 uprising. What really leaves little doubt, however, as to the connection this non-school has to the Zapatista movement, is their embrace of the concept of autonomy.

So, what does it mean to say that a school or university is autonomous? What does it mean to say that Unitierra is autonomous? Autonomy here should be conceived as the creation of a life at a distance from the State - not simply the local, state, and national government - although in a very strict sense that is 
exactly what the Zapatistas have done. To be an EZLN autonomous community or family is to accept nothing from the official government - any advice, gifts, help, resources or anything. And to do otherwise, even if it is a small bag of cement or the 2,000 pesos (US\$170) that the government sometimes provides for campesino families to help them between harvests, is to be expelled from the movement and the governing and military structures that define it. The strict avoidance of involvement in all State-sponsored institutions has been quite controversial - with many families and communities being dropped the movement for simply sending their children to the local, governmentsponsored schools. ${ }^{2}$

However, this question of living at a distance from the State is more than simply not participating in official governing institutions. ${ }^{3}$ Although created in the early 1970s Deleuze and Guattari's conception of the Urstaat - what they used to refer to the earliest, original manifestation of the State - is arguably one of their most important political conceptual innovations. It is the Urstaat that creates the kinds of collective subjectivities that ensure that productive labour and accumulation find their way into every aspect of contemporary life. ${ }^{4}$ This is an especially important concept for understanding what is at issue for this indigenous-led social movement that has been working toward the creation of

2 The autonomous rebel municipalities that make up the movement are organized around six different locations of government spread out through the eastern half of the state that are called caracoles (snails) and serve as collective centres of decision making designed to foster a life and existence outside of the purview of official, local, state, and national government - at least in terms of how these institutional structures have habitually been conceived. In each caracol there is a diverse range of on-going autonomous education projects that serve as the formal education outlet for Zapatista youth.

3 A fact that differentiates the Zapatista attempt to defend collective forms of life and social organization (including education) from the hyper-individualistic libertarian current that dominates global capitalism today beneath the veneer of 'freedom' that is celebrated by the profiteers of the marketplace - a trend that inevitably fails to differentiate between a critique of government and a critique of the State As anthropologist Viveiros de Castro (2010) has pointed out, the individual and all of the rights granted to the protection of individuality over and above the socius are dependent upon the State for protection. A society with a State is a society that is thoroughly divided, bound together only through the desire of the despot who serves as a model for the individuals created from the division in the socius. As a result, Castro rightfully claims that 'the individual is a product and correlate of the State ' (p. 30). The result of this confluence of concepts that regularly utilizes the term 'government' interchangeably with 'the State' is that the state becomes interchangeable with society, so that each individual has become its own State. The individualism bound up with freemarket libertarianism gives birth to a million little states. Or, as the case is in the US, 300 million little States.

4 It is also an aspect of Deleuze and Guattari's political work that makes it impossible to genuinely engage with their thought in terms of something along the lines of policy - educational policy or otherwise - for at the core of policy is the inherent presumption that one group of people knows what is best for another. As David Graeber (2004) states, 'the notion of policy presumes a state or governing apparatus which imposes its will on others. "Policy" is the negation of politics; policy is by definition something concocted by some form of elite, which presumes it knows better than others how their affairs are to be conducted ... it is inimical to the idea of people managing their own affairs' (p. 9). 
an autonomous existence based on the simultaneous defence and re-creation of pre-colonial forms of collective life - a life whose autonomy is based on the elimination of the State from its presence.

So, for Deleuze and Guattari, what exactly is the State? It is well known that Deleuze and Guattari's work on the State emerged out of a sustained engagement with the work of anthropologist Pierre Clastres who questioned the evolutionary theories endemic to Marxist theories of societal change that traditionally viewed the emergence of the State as the result of the appearance of increasingly complex forms of socio-economic life - a life that grew in tandem with the spread of the capitalist division of labour. By contrast, Clastres posited that the State is something that has always existed, and that those who have managed to avoid its grasp are those peoples (specifically 'primitive' peoples for Clastres) that created the kinds of socio-cultural mechanisms that worked to avoid the imposition of the State. In other words, the earliest/original forms of Stateliness (the Urstaat) - the consolidation of power in a few hands; the hierarchical organization of society; a monopoly in the 'legitimate' use of violence; and the ability to forcibly extract profit/riches from the work of others, is always lurking around the corner. While this ideal State has been enacted to varying degrees of success, such despotism has served as the 'horizon' of all that the State desires to be. Those who have managed to avoid such Ur-aspects of Stateliness did so not as a result of an accident, luck, or an 'undeveloped' form of socio-economic organization that predated the advent of capitalism, but rather through a form of socio-cultural organization intentionally designed to prohibit, or limit the possibility of the formation of the State. Why have 'primitive' peoples organized themselves around deterring the formation of the State? Precisely because they were well aware of the consequences of its emergence. ${ }^{5}$

It is frequently argued, that the spread of neo-liberal global capitalism has rendered the State -specifically the nation-state - impotent in the face of the decodifying and deterritorilizing aspects of our economic reality. While capitalism works in a decodifying capacity in the way that it breaks down territories, languages, traditions, ways of life, social connections, and the decision-making capacities of local and national governments, among other things, the State functions by way of capture. Instead of the dissolution of the State in the face of these massive deterritorializing aspects of the global economy - an assumption that is believed to be true to the degree that one

See Graeber (2004) and Clastres $(1987 ; 2010)$ for more on this argument regarding 'primitive peoples' and the State. 
believes that the State is that which works alongside the socio-economic sphere - the despotic aspects of Stateliness have now begun to invent new codes (1983, p. 218). In other words, the despotism of Stateliness has also been released to work in conjunction with neo-liberal global capitalism to the point that it now has begun to seek out new territories to code. No longer is the State oriented toward capturing those territories existing externally to the socius - in the form of what Marx famously called primitive accumulation - but is now oriented toward the codification of internal territories (where primitive accumulation is also now directed inward), making the State indistinguishable from society. While limits are overcome or deterritorialized in neo-liberal capitalism, they are overcome only in order to be more stringently reterritorialized or captured in a way that makes them seem immanent to the State/capital bond (Toscano, 2005 , p. 45). What is more, is that with increasingly complex advancements in communication technologies, the forms of primitive accumulation aimed at the interior of the socius and the capture of the affects, desires, and emotional energies of the populace seem to be limitless.

Although there are certainly specific axioms at work in neo-liberal global capitalism - ones that work to ensure the proliferation of capitalist accumulation in new territories, there are also specific values - not unrelated to the dominance of surplus value - but also in line with how one chooses to live a life. In thinking about State and capitalist axioms, we must ask what kinds of values are produced that grow in tandem with their sustenance and expansion. Such values that are bound hand and foot to today's neo-liberal global capitalism include increasing forms of competition, envy, and greed that are all directed toward the erasure of the remaining commons, the destruction of our environment, and spreading of non-democratic polities, among other things.

The project of autonomous education and the project of Unitierra work to uncouple indigenous Mayan peoples from the contemporary social values that have been mapped upon the land and its inhabitants since the foundation of the nation. These are the same kind of social values born out of the cartographic markers that appeared over 500 years ago and slowly built up over time to the point where State and society are no longer distinguishable - a cartography that quantified and domesticated Mayan peoples and their lands as so many men and women; sources of gold; potential slaves (depending on their size and physical strength); so many heads of sheep; so many acres of wood; and so many potential votes guaranteed through the donation of a few extra bags of cement.

Here we should think of the Spanish word for State due to the way it serves as a clue to the operation of Stateliness in the context of formal education in 
Mexico - especially with regard to the poor or those living on the margins of the nation. The word for State in Spanish is Estado. However, this word also refers to being - specifically, the past participle of estar 'to be' that not only indicates a specific kind of being, but also insinuates some kind of ossification of that being - as in what you are now could very well continue into the foreseeable future. To think the State - is necessarily to conceive of the capture of being to ensure what has been will continue as it is and remain immanent to the State/ capital nexus. To continue as it is, is to be part of the strict segmentarity inherent in the State and its capitalist axiological machine that spreads itself out to the point of simultaneously extinguishing the appearances of any singularities while dissolving the separation between State and society. ${ }^{6}$

In this context we can understand the education system of the nation-State as a kind of mapping where el estado is dead set on continuing the 500-year-old process whereby what was at its very inception continues to be. Mapping its calculating rationality and its inherent infusion of value onto those things that come under its purview, is nothing less than the physiognomy of the State that makes itself evident in formal schooling by constituting the parameters around which indigenous students are to understand themselves within the sociocultural and neo-liberal economic context of contemporary Mexico. These students are identified as so many sources of cheap labour; potential voters to be bought off; and inhabitants of communal lands whose value is marked in dollar signs (the very thing that Marx identified as magical, in the supposedly very secular universe of capital).

In the case of the Zapatistas, their criticism has historically been directed toward what they call el mal gobierno (the bad government). The mal gobierno is a government that relies on a system of co-optation through vote fixing and partronage for coletos (those who claim Spanish ancestry) and the landed elite that has existed in uninterrupted form since the annexation of Chiapas from Guatemala in 1824. Of course, during this time, there have been countless examples of indigenous uprisings and organized violence against the State and the political elite, of which the Zapatistas from 1994 are only a continuation.

Unitierra is a product of this history. It continues to be an attempt to create a centre of learning that is not a 'school' but rather a new kind of education that allows indigenous youth from around the state a chance to acquire skills and apply them to the creation of a life - una buena vida (a good life) that is

\footnotetext{
6 See Eduardo Viveiros de Castro (2010) for more on the way that the non-existence of singularities are related to the subsumption of the State by society.
} 
specifically opposed to una mejor vida (a better life). As it has been explained to me, una buena vida is a life disentangled from the desire and greed inherent in endless accumulation, and is instead indicative of an ethos that works to escape the rendering of their existence through the eyes of el mal gobierno. Una buena vida does not entail the constant drive for betterment - for 'a better life' necessitates constant competition and the striving for an existence that puts all of our survival in jeopardy.

To think of how our existence could be otherwise - this State of things and being - is necessarily to think about an autonomous life. To be autonomous is to be free of the cartographic markers that determine Stately being - and as such to reconsider the way that formal education takes place.

\section{The pedagogue of objects and the gas generator at Unitierra}

Célestin Freinet, the great French teacher and philosopher of education who worked in rural France in the early to mid-twentieth century influenced a range of activities and research related to group dynamics in institutional settings. As a result of his work as a teacher, Freinet served as the one of the primary intellectual influences in the development of what came to be known as 'Institutional Pedagogy' - a psychoanalytic and urban initiative based in Paris and by Jean and Fernand Oury that focused on better understanding the relation between the unconscious of students and processes of learning. Although primarily uninterested in issues pertaining to psychoanalysis, Freinet's work in the classroom served as a great inspiration for the Oury brothers and eventually for Félix Guattari as well; particularly in terms of creating new kinds of group work that challenged the traditional static and hierarchical organizational forms endemic to institutional life. Most notable of these organizational innovations was 'the grid' - a schedule at La Borde clinic where Oury and Guattari worked that attempted to alter the traditionally defined roles and responsibilities of everyone that worked there, including those of patients and analysts. As one of the primary intellectual influences of institutional pedagogy, Freinet is typically described as a tireless advocate for the democratization of the classroom that proceeded through a collaborative approach to student writing and work. This characterization of Freinet as a champion of student initiates and collaborative learning places him firmly within the context of the 'child-centred' educational philosophy of Maria Montessori, Rudolf Steiner, John Dewey, Olvide Decroly and others that was emerging in the early twentieth century. While 
these characterizations are true to some degree, they do not fully account for Freinet's innovations. His most enduring contribution to pedagogy was to do with how he conceived of and utilized objects as a centre-piece of his approach to teaching and learning. For Freinet, objects were not ancillary to the more pressing concerns of the ideological role played by curriculum, but rather the driving force in changing the organizational dynamics and social relations of the classroom. Freinet's approach to liberating the classroom from the organon of the State - appearing as much in the dogmatism and reifying dimensions of traditional government-sponsored pedagogy as it did in the French Communist Party's approach to education - was to place objects at the foreground of his teaching and thus place his trust in the power of organization.

Why is Freinet the pedagogue of objects? Freinet is known for placing a printing press in the middle of his classroom. Although he was not the first to utilize a printing press in the classroom, he became well known for using it as a centre-piece in incorporating work and initiating collective-writing projects into the classroom on subject matter decided upon by the students themselves. Strangely enough, his use of the printing press was, at least in part, due to a serendipitous lung injury he sustained in the First World War that made it difficult for him to stand and lecture in the traditional way that teachers in France were trained to do in the early part of the twentieth century. While never specifically discussing the role of objects in his teaching, his use of the printing press in the classroom suggests that he regarded them as conceptual tools, that when unleashed within the context of a classroom had the potential to change the kinds of predetermined relationships that typically existed between students, students and teachers, and also between students and their own work in French schools.

Through the introduction of the printing press into his classroom, the classroom was fundamentally changed. This changed was played out through the appearance of one object and the corresponding disappearance of another. The printing press was placed in a central location in the classroom and, as a result, the podium was eventually removed from its primary position in the front of the classroom. The basically teleology of the classroom and how learning was to occur was fundamentally altered as the teacher now longer occupied the same place of authority. A more diverse range of activities and subjects began to be reintroduced into the classroom, not through the implementation of specific curricula, but rather through the aggregate that was created as the students began to engage with and became plugged into the new object that suddenly stood before them as a centre-piece of their learning 
environment; connecting them to topics and readings they would never have engaged with otherwise. Traditional hierarchical relationships in the classroom began to dissolve including that between the students and the teacher. It was the introduction of the object and the work on and through this object taken up by the students that formed new collective learning processes and forms of social organization that helped the classroom become completely free of the limitations, rules, relationships, and regulations that saw students sit rigidly in front of the teacher as he recited pre-prepared lessons on history, the nation, and the culture in which they found themselves.

The investigations initiated by the students that often took them into their community, typically focused on topics and issues related to them and their families' lives in the farming community surrounding the school. These student-driven investigations that took them on explorations into their own communities, along with the corresponding collaborative forms of writing and care of the printing press, formed the basic elements of Freinet's emphasis on work and vocationalism. ${ }^{7}$ Freinet's focus on work in the classroom did not take the form of instrumental training, but rather as something conceived of as integral to and indistinguishable from the kind of collective organization of social life they wanted to create beyond the bounds of their institutional setting. The result was that the practice of teaching and the life of the school became free from their traditional forms of support and legitimacy as students, within an institutional setting, became actively engaged in the social life of their community.

New assemblages began to be created within the confines of Freinet's classroom, replacing traditional, institutionally designed directives and government mandated forms of teaching and learning that emanated outward from the platform and lecture format that accompanied it. The end result was a release of new desires that escaped the impasses of the State. With the arrival of the printing press, the State was subtracted from Freinet's classroom; serving as a foil to the institution's intention to 'conserve."

For Deleuze (1993), this act of subtraction was exactly what was at work in the plays of Carmelos Bene. It was Bene's theatre, Deleuze argued, that brought traditional plays to life not through criticism, but rather through alterations to the characters that typically drove the story lines and determined the kinds of

7 The investigations often had to do with exploring the kinds of work that was taking place in their community.

8 For Deleuze and Guattari (1987) the goal of the State is always to conserve and this is exactly why we can speak of the State in terms of its Spanish translation as el estado (p. 357). 
sets used in the traditional rendering of the plays he was working with. These alterations took the form of what Deleuze (ibid.) described as 'subtractions' and 'amputations' from the original production. For Deleuze, Bene's act of subtraction of specific characters from a play, 'gives birth to and multiplies the unexpected as in a prosthesis' that brings to life the potentiality of characters that were previously masked (p. 205). In one example, Bene 'amputates Romeo from Romeo and Juliet, awakening the previously dormant qualities of Mercutio's life for the first time. For Deleuze, the way that Bene alters a play so as to render it anew made him less of a director than a 'surgeon' or an 'operator' in the sense that these procedures of modification to the body of the play had to take place with absolute precision. In some examples, Bene s amputates characters such as Romeo; while in others, he amputates entire structures of power from the plays, like what he did to the rival families in his interpretation of Richard the Third.

Particularly significant is the way that Deleuze reminds us that Bene's acts of subtraction not only change the actual materials in the theatre, but also the 'representational' logic that produces it. By taking away primary, 'stable' components necessary for the reproduction of theatre as 'representational', his creations become a permanent space of 'disequilibrium' that escape the State's desire to conserve. For Deleuze, Bene's work as a surgeon of the theatre becomes the work of a war machine (ibid., p. 207). ${ }^{9}$

If we transpose Deleuze's thought about Carmelo Bene's plays into the context of school where the classroom becomes a theatre with a set and the teacher is conceived as an 'operator', similar questions arise with regard to the dynamics of power; namely, how does one extricate a genuine education from a State education, and how does one extricate genuine thought from the thought of the State?

With Bene, as well as with Freinet, such a process of escaping the State does not occur through mere ideological alterations - which in the case of the theatre, Deleuze reminds us, would amount only to the creation of parody or the adding of literature to literature (ibid., p. 205). With school, the focus on ideology most frequently yields a change in the wording in the curriculum a critique of power focused on alterations to language. A genuine education and thought, however, appear at the point that changes in the organizational dynamics of the institutional setting create new kinds of prostheses that are able to avoid the kinds of impasses that have become standardized - impasses

9 Deleuze compares this approach to theatre to the work of Brecht who is focused on the written word and not the stage (p. 212). Next to Brecht's prioritization of the ideological, Bene's focus on the organization elements of the stage become more clearly identifiable. 
that determine the way that students learn and the people within the classroom relate to one another. For Deleuze, the power that is on display in educational settings is less a product of ideology than it is reflective of the organization of the people within that space; the groups that are formed; the interactions that take place; and the decision-making processes that emerge from such groups.

For Bene, the reorganization of theatre that allows for the potential to extricate plays from the representational logic of the State of things operates by way of a subtraction that focuses on the role of new characters that had previously been concealed from view. It is the characters that give 'caprice' to the objects that surround them - infusing them with significance and determining their utility.

While Freinet's intentions are similar, his approach to the set of his classroom operates through an opposing logic. Instead of subtraction, he adds, and instead of prioritizing characters/students he prioritizes objects. It is the objects for Freinet that give 'caprice' to the students. Something leaves the scene, but the process of subtraction is less drastic, less immediate - not so much reliant on a cut as it is a deterioration. Amputation occurs, but the amputation is the end result of a growing uselessness. The great object of the State in the classroom - the platform - that enables the professor to profess and thus granting him the power to instil in his subjects all of the representational logic inherent in their culture, their history, and the curriculum that reproduces the French nation - is rendered useless in a similar way that particular objects of the set of Romeo and Juliet became frivolous upon the amputation of Romeo. However, it is the new prosthesis created through the interaction of the students and the printing press in Freinet's classroom that renders the platform useless; dead; and withered to the point that it falls away. Through addition in Freinet's classroom, the State is removed.

The printing press that was introduced into Freinet's school carried no predetermined prescription; nor did it carry any predetermined intention or aim. In each object, there are various dimensions and limitations (both affective and useful) that determine the specific potentialities that exist as part of any situational aggregate. However, as Guattari (1995) reminds us, everything depends on its articulation within collective assemblages of enunciation' (p. 5). In this case, the printing press and its potential was situated in the middle of the classroom space and utilized in a way that the act of learning became entwined with a process of collective social organization. The end result was that the classroom escaped the traditional subjection of student energies to the whims of the State, transforming the space of Freinet's school and his students' work into a source of micropolitical activity. 
So what does the work of the pedagogue of objects have to do with Unitierra? The description at the beginning of this chapter was written with the intention of focusing on some of the visible objects that make up Unitierra. This was not done with the sole intention of creating a mise-en-scène so much as to bring attention to the aesthetic of the place and the objects that compose it. It is this world of both conceptual objects in the form of autonomy and education, along with the material objects of buildings, materials, colours, plants, and animals that come together to evoke the world that is Unitierra.

But of course, this is not a democracy of objects - all the objects that make up Unitierra are not the same, nor do they assume equal importance in the creation of this autonomous educational project. Some of these objects have a distinct importance in terms of facilitating the existence of this place - one such object is the gas generator that exists within the confines of a brick structure about 14 -feet high and 10-feet wide. There is nothing particularly exceptional about this structure - it is a simple brick building with a roof made of red clay tiles and a green painted wooden door on the side with painted murals covering the outer walls that depict scenes from rural, indigenous life in Chiapas. From the top of this structure a cloud of black soot spews out in tandem with a loud humming of a machine - a humming that can be heard around campus.

When one enters Unitierra it might be easy to ignore this structure; after all it is surrounded by much more important-looking buildings that are bathed in bright paints with neatly kept cobbled walkways that weave in and out of the buildings, greenhouses, duck ponds, and rabbit hutches that sit on the hill opposite the main entrance. However, there is no other object that is so central in enabling this project of autonomy to exist. With this object, the students and workers here are able to physically and materially uncouple themselves from the dependence on the federal government and all the associated forms of patronage and manipulation that have gone hand-in-hand with this colonial relationship over the last 500 years. The creation of Unitierra, as well as its on-going development and use, is absolutely dependent on the existence and maintenance of the gas generator that provides the electrical and material power necessary to create this autonomous territory out of nothing.

As one moves through the university, walking in and out of the buildings and around the campus, one becomes plugged into these rumblings in the same way that every building, machine, and classroom is also plugged into the energy that emanates from it. There is something rightly anarchic, and formless about the sound as it moves and reverberates between and within buildings, and then seeps through the chain-link fence that surrounds the land, drawing 
and expanding upon the desire for an autonomous life as it touches the students and teachers that live there. To this end, the object is not just a product of the imputation of value from within to without - an idiosyncratic or social value projected into an object that surrounds us - but also simultaneously a holder of a particular organizational potential and value within the context of this group in much the same way that the printing press served as a focus of collective work in Freinet's classroom. It is the gas generator within this collective educational formation that has provided Unitierra with the capacity to focus on the removal of particular inhibitions that have been in place for generations particularly the ability to work together and participate socially outside of the confines of their own communities and within institutional settings of their own making. ${ }^{10}$ Without such a physical uncoupling from the State that the gas generator enables, the contact between people would be largely determined by the capitalist ethos and the concomitant privatization of reproduction that dominates every sphere of Mexican life.

Deleuze argues that what Bene's rendition of the life of Marquis de Sade indicates through the amputation of the sadistic master is that, 'the slave is not at all the reverse image of the master, nor his replica nor his contradictory identity: he constitutes himself piece by piece, morsel by morsel, through the neutralization of the master; he gains his autonomy through the master's amputation' (p. 205). Although in many cases, Zapatista autonomous education projects are often forced initially to rely on the spaces, methods, organizational techniques, and curriculum of the State (in many instances that is all they have ever known), the uncoupling from the government structures that have created a debilitating relationship between indigenous peoples and the nation of Mexico has allowed for the possibility of the extrication of the master.

To conclude, the gas generator is the source from which the on-going reconceptualization of education by and for indigenous students proliferates - their anarchic experimentations with new ways of learning remaining intact. In this way Unitierra exists as a pedagogical lesson of sorts through the ways that it provides a salient example of how education can depart from the status of a State institution through the addition of objects that lead to the reorganization of the social life of institutions. The school is what has been left behind at Unitierra, and in its place is an education of open constitution - one that works to prepare

${ }^{10}$ See Guattari (1995) for a further discussion about the importance of removing those kinds of superego-induced prohibitions that limit peoples' ability to participate socially (p. 146). 
students for an autonomous life, 'a good life', and a life organized outside of the purview of the State.

\section{References}

Berardi, F. (2012) The Uprising: On Poetry and Finance. New York: Semiotext(e). Clastres, P. (1987) Society Against the State. New York: Zone Books -(2010) Archeology of Violence. New York: Semiotext(e).

Deleuze, G., and Guattari, F. (1983) Anti-Oedipus: Capitalism and Schizophrenia. Minneapolis, MN: University of Minnesota Press.

Deleuze, G. (1993) The Deleuze Reader, ed. C. Boundas. New York: Columbia University Press.

-(2009) 'Capitalism: A Very Special Delirium', in F. Guattari (ed.), Chaosophy: Text and Interviews 1972-1977. New York: Semiotext(e).

Deleuze, G. and Guattari, F. (1987) A Thousand Plateaus: Capitalism and Schizophrenia. Minneapolis, MN: University of Minnesota Press.

Graeber, D. (2004) Fragments of an Anarchist Anthropology. Chicago: Prickly Paradigm Press.

Guattari, F. (1995) Chaosmosis. Bloomington, IN: University of Indiana Press. Sánchez, R. (2005) 'Entrevista con Dr Raymundo Sánchez Barraza, 8 de Julio, 2005, Chiapas'. Available at http://autonomiazapatista.com/Entrevistas/entrevistas_2.html, $12 / 6 / 2012$.

Toscano, A. (2005) 'Capture', in A. Parr (ed.), The Deleuze Dictionary. Edinburgh: Edinburgh University Press.

Viveiros de Castro, E. (2010) 'The Untimely Again' in P. Clastres, Archeology of Violence. New York: Semiotext(e), p. 9-51. 